\title{
Two Phytotoxins from Stagonospora sacchari Causing Leaf Scorch of Sugarcane
}

\author{
P. Venkatasubbaiah*, Keisuke Kohmoto*, Hiroshi Otani*, \\ Takashi Hamasaki*, Hiromitsu Nakajima* and Kazuo Hokama**
}

\begin{abstract}
Several isolates of Stagonospora sacchari causing the leaf scorch disease of sugarcane were found to produce at least two phytotoxins (toxin I and II) in cultures as well as in spore-germinating fluids. Toxin I and II were isolated and chemically determined to be 6-methylsalicylic acid and (+)-epoxydon, respectively. Their threshold concentrations inducing leaf necrosis on susceptible cultivars of sugarcane were $30 \mu \mathrm{g} / \mathrm{ml}$ for toxin I and 25 $\mu \mathrm{g} / \mathrm{ml}$ for toxin II, whereas resistant sugarcanes and many nonhost plants, except maize and sorghum, were more tolerant to the toxins. The toxins caused a rapid increase in loss of electrolytes from leaf tissues. Potassium was the prominent cation species in the leaked electrolytes. There were significant correlations between susceptibility to the leaf scorch and toxin sensitivity with toxin I and II among sugarcane cultivars examined.
\end{abstract}

(Received January 24, 1987)

Key words : phytotoxin, 6-methylsalicylic acid, (+)-epoxydon, Stagonospora sacchari, sugarcane.

\section{Introduction}

Sugarcane, Saccharum officinarum L., is an important cash crop in many tropical countries. Diseases of sugarcane have caused immense losses to the sugarcane industry. The leaf scorch disease of sugarcane caused by Stagonospora sacchari Lo et Ling ${ }^{11)}$ is a serious threat to the sugarcane cultivation in tropics, sub-tropics and temperate countries including Okinawa islands in Japan ${ }^{6-8,10,13)}$. Heavy losses have frequently been reported with certain cultivars of the crop under favorable conditions to the pathogen. In Okinawa islands the disease has become epidemic and is causing serious economic damages every year ever since the ratoon cultivation using newly introduced cultivars such as IRK67-1 and NCo310 was started in sugarcane fields during mid $1960 \mathrm{~s}^{5.7}$.

The pathogen caused yellow or reddish brown tiny lesions on susceptible sugarcane leaves 24 to $48 \mathrm{hr}$ after infection by spores ${ }^{10,13)}$. These initial spots gradually elongated with time and formed more or less spindle shape surrounded by yellowish halo, and eventually they became reddish brown streaks by running together. Such symptom development and severity in scorching leaf tissues are suggestive of a possible involvement of pathogen-produced phytotoxin in the disease. However, there is no report on

* Faculty of Agriculture, Tottori University, Tottori 680, Japan. Present address of first author (P. V.) is Microbiology Division, Central Food and Technology Research Institute, Mysore 570013, India. 鳥取大学農学部

** Okinawa Prefectural Agricultural Experiment Station, Naha, Okinawa 903, Japan 沖緡県農業試 験場 
the production of phytotoxin by S. sacchari and its significance in the disease development.

The objectives of the present study were: 1) to isolate and purify toxins from cultures of S. sacchari, 2) to elucidate their chemical structures, and 3) to examine the relation between disease susceptibility and toxin sensitivity among sugarcane cultivars. A brief report of the study has been published previously ${ }^{19)}$.

\section{Materials and Methods}

Plants. Ten different cultivars of sugarcane, comprising of susceptible (IRK67-1, NCo310, Co290, CP43-32 and CP36-105) and moderately resistant (NCo376, RK82-1049, RK65-37, POJ2878 and F160) cultivars, were used and maintained in a greenhouse. As many as 20 nonhost plants were also grown under glasshouse conditions for the studies.

Pathogen. Pure cultures of Stagonospora sacchari were isolated from the diseased sugarcane leaves obtained from Okinawa islands of Japan in 1985. A virulent isolate, SSI-1 from susceptible cv. IRK67-1 was mostly used for the isolation of toxins. Other isolates such as SSN-1, SSN-2 (pycnidial), SSN-3 and SSN-4 from cv. NCo310, SSN-5 from cv. NCo339, SSI-2 and SSI-3 from cv. IRK67-1, SSH-1 from cv. H32-8560 and SSM-1 from cv. M93-48 were used for comparative studies on their pathogenicity. The stock cultures of the isolates were maintained on potato dextrose agar slants. The pathogenicity of the isolates was tested by inoculating small amounts of spore suspension on excised leaves of susceptible and moderately resistant sugarcanes.

Pycnospores were collected from 20-day-old mycelium mats grown on potato dextrose broth at $26 \mathrm{C}$. The spore concentration was adjusted to $1 \times 10^{5} \mathrm{spores} / \mathrm{ml}$. Leaf tissues (size: $5.0 \times 2.5 \mathrm{~cm}$ ) of sugarcane cultivars were wounded slightly at the center with a needle and $30 \mu 1$ of the spore suspension was placed on it. The inoculated leaf tissues were incubated in a moist plastic chamber at $26 \mathrm{C}$ for $72 \mathrm{hr}$. The disease incidence was recorded by measuring the necrotic area developed and was grouped into the four, i. e., the highly (over $2 \mathrm{~cm}^{2}$ ). moderately $\left(1-2 \mathrm{~cm}^{2}\right.$ ), slightly damaged (less than $1 \mathrm{~cm}^{2}$ ) and no necrosis.

To isolate the toxin, an agar block from the 8-day-old virulent SSI-1 isolate was incubated in $500 \mathrm{ml}$ bottles containing $200 \mathrm{ml}$ potato dextrose broth at $26 \mathrm{C}$ for 20 days under stationary condition to obtain maximal toxin production.

Leaf bioassay for toxicity. Phytotoxicity was investigated using leaf-necrosis assay on susceptible sugarcane cvs., IRK67-1 or NCo310. The detached leaves were cut into small pieces $(2 \times 4 \mathrm{~cm})$ and center of them was wounded slightly with a needle. The wounded pieces were placed on the moistened sponge mats in a moist chamber and sample solutions (about $50 \mu \mathrm{l}$ ) were dropped on the wounded portions. The chamber was kept at $26 \mathrm{C}$ for $24-72 \mathrm{hr}$. A characteristic spindle shaped, brown necrotic lesion with red margin occurred within $24 \mathrm{hr}$ was regarded as an indication of the presence of toxin in the sample solution. In many cases the sample solutions were serially diluted with distilled water to determine the maximum dilution end point for necrotic lesion formation. The responses were recorded 24 to $72 \mathrm{hr}$ after treatment. 
HPLC analysis. A Hitachi 655 liquid chromatograph equipped with variable UV monitor 638-41, Rheodhyne 7125 injector fitted with $20 \mu \mathrm{l}$ sample loop and pre-packed Wako LiChrosorb RP18-7 column $(4.6 \times 250 \mathrm{~mm})$ was employed. The toxins I and II were eluted at $0.6 \mathrm{ml} / \mathrm{min}$ flow rate by using methanol-water-acetic acid, $90: 10: 1 \mathrm{v} / \mathrm{v}$ and methanol-water, $25: 75, \mathrm{v} / \mathrm{v}$, respectively. The detector wavelength for toxin $\mathrm{I}$ was $308 \mathrm{~nm}$, and for toxin II $237 \mathrm{~nm}$. Samples were injected as methanol solutions.

Electrolyte leakage. Electrolyte leakage and several cation effluxes from leaf tissues were determined by the method described previously ${ }^{14)}$. Five discs $(1 \mathrm{~cm}$ in diameter) were cut from sugarcane leaves with a leaf punch, and then vacuum-infiltrated with various concentrations of toxins or distilled water for $20 \mathrm{~min}$. The discs were rinsed in distilled water and were transferred to polyethylene tubes containing $10 \mathrm{ml}$ distilled water. The tubes were incubated in a reciprocal shaker $(90$ strokes $/ \mathrm{min})$ at $26 \pm 1 \mathrm{C}$. The discs were transferred to another $10 \mathrm{ml}$ distilled water at every one hour interval. Amounts of electrolytes were measured with an MS conductivity meter with dip type cell $(k=1.0)$. Amounts of potassium, sodium, calcium and magnesium in ambient solutions were determined with a Hitachi 170-30 atomic absorption spectrometer.

Spectral analysis. UV spectra were recorded on a Hitachi 100-50 spectrophotometer. IR spectra were taken with a Hitachi 295 infrared spectrophotometer using pellet of $\mathrm{KBr}$ disc. NMR spectra were recorded on Hitachi R-24 and JEOL JNM-GX 270 spectrometers. Optical rotations were measured on a Yanagimoto OR-50 polarimeter. Mass spectra were obtained with a Hitachi RM-50 spectrometer (ionization voltage, $70 \mathrm{eV}$ ) using a direct inlet system.

\section{Results}

\section{Isolation of toxins from culture filtrate}

Drops of cell-free filtrate of virulent isolate SSI-1 induced the characteristic necrotic lesions on susceptible leaves within $24 \mathrm{hr}$. Therefore, to isolate toxin the culture filtrate (10 liters) was adjusted to $\mathrm{pH} 3$ with $6 \mathrm{~N} \mathrm{HCl}$, extracted four times with ethyl acetate, and then the extracts were evaporated to dryness in a rotary evaporator under reduced pressure at $40 \mathrm{C}$. The water phase was discarded because of its very low toxicity. The toxic materials in ethyl acetate phase was chromatographed employing silicic acid column (Wakogel C-200, column size: $4 \times 52 \mathrm{~cm}$ ). When $500 \mathrm{ml}$ aliquots of chloroform containing $0,1,2,4,10$ and $100 \%$ methanol were passed serially through the column, the toxins were eluted with the first two solvents and chloroform with $10 \%$ methanol. The concentrated former two fractions gave pale yellow crystals, which were crystallized in chloroform to obtain colorless needle crystals yielding $2.20 \mathrm{~g}$. It was designated as toxin I for convenience because of its phytotoxicity. The other toxic fraction eluted with chloroform containing 10\% methanol was serially subjected to preparative TLC (solvent mixture: chloroform-methanol, 3:1, v/v, \& developed twice), then to Sephadex LH-20 column chromatography $(2 \times 132 \mathrm{~cm})$. The column was eluted with $500 \mathrm{ml}$ methanol at a rate of $1.7 \mathrm{ml} / \mathrm{min}$, and each $15 \mathrm{ml}$ fraction was collected. 
Only three fractions, nos. 24-26, exhibited phytotoxicity. After evaporation they gave colorless syrup yielding $235 \mathrm{mg}$, which was designated as toxin II. Remaining fractions were devoid of any toxic materials. Toxin I and II respectively migrated as a single compound on TLC plates (Merck's Kieselgel Type 60, F-254) with different solvent systems as shown in Table 1, when they were monitored by the following reagents: $\mathrm{H}_{2} \mathrm{SO}_{4}-\mathrm{KMnO}_{4}$, conc. $\mathrm{H}_{2} \mathrm{SO}_{4}, \mathrm{H}_{2} \mathrm{SO}_{4}-\mathrm{K}_{2} \mathrm{Cr}_{2} \mathrm{O}_{7}, \mathrm{I}_{2}$ and UV-quenching (254 nm). Toxic zones detected by leaf necrosis assay coincided with these spots. All the isolates tested were found to produce both toxin I and II in their cultures.

Table 1. Rf values of toxin I and II on TLC developed with different solvent systems

\begin{tabular}{l|c|c}
\hline \hline \multicolumn{1}{c|}{ Solvent system (v/v) } & \multicolumn{2}{|c}{ Rf value } \\
\hline Benzene-acetone, $1: 1$ & Toxin I & Toxin II \\
Benzene-ethyl acetate-acetic acid, $50: 50: 1$ & 0.45 & 0.46 \\
Benzene-acetone-acetic acid, $60: 40: 1$ & 0.52 & 0.18 \\
Benzene-acetone- $n$-hexane-acetic acid, $50: 20: 20: 1$ & 0.59 & 0.36 \\
$n$-Butanol-acetic acid-water, $4: 1: 1$ & 0.34 & 0.13 \\
Chloroform-methanol, $9: 1$ & 0.89 & 0.68 \\
Chloroform-methanol, $3: 1$ & 0.38 & 0.34 \\
Chloroform-ethyl acetate- $n$-hexane-acetic acid, $50: 25: 25: 1$ & 0.55 & 0.67 \\
Isopropanol-ammonia water (28\%)-water, $10: 1: 1$ & 0.29 & 0.0 \\
\hline
\end{tabular}

\section{Identification of toxin $I$ and $I I$}

Toxin I was colorless needles (chloroform-methanol), m. p. $170 \mathrm{C}$, and positive for both bromophenol blue and $\mathrm{FeCl}_{3}$ (violet). The physicochemical records of this toxin are as follows. UV $\lambda_{\max }^{\mathrm{EtOH}} \mathrm{nm}(\varepsilon): 212(20,400), 237(6,800), 303(4,000) . \quad$ IR $\nu_{\max }^{\mathrm{KBr}}$ $\mathrm{cm}^{-1}:$ 3000, 1660, 1608, 1450, 1313, 1257, 1223, 912, 808. Found: C, 63.12; H, 5.22, Calcd. for $\mathrm{C}_{8} \mathrm{H}_{8} \mathrm{O}_{3}: \mathrm{C}, 63.15 ; \mathrm{H}, 5.30 \%$. MS m/z: $152\left(\mathrm{M}^{+}, \mathrm{C}_{8} \mathrm{H}_{8} \mathrm{O}_{3}\right), 134\left(\mathrm{M}^{+}-\mathrm{H}_{2} \mathrm{O}\right)$. ${ }^{1} \mathrm{H}-\mathrm{NMR}$ $\delta_{\mathrm{TMS}}^{\left(\mathrm{CD}_{3}\right)_{2} \mathrm{CO}}: 9.83(2 \mathrm{H}$, broad), $7.16(1 \mathrm{H}, \mathrm{dd}, J=7.6,6.4 \mathrm{~Hz}), 6.63(1 \mathrm{H}, \mathrm{d}, J=6.4 \mathrm{~Hz})$, $6.60(1 \mathrm{H}, \mathrm{d}, J=7.6 \mathrm{~Hz}), 2.52(3 \mathrm{H}, \mathrm{s})$. From these data, toxin I was identified with $6^{-}$ methylsalicylic acid (6-MSA).

Toxin II was an oil, $[\alpha]_{D}^{25}+88.2^{\circ}(\mathrm{c}=0.06, \mathrm{MeOH})$. UV $\lambda_{\max }^{\mathrm{MeOH}} \mathrm{nm} \quad(\varepsilon): 237$ $(4,900)$. IR $v_{\max }^{\mathrm{KB} \mathrm{r}} \mathrm{cm}^{-1}: 3400,1690,1400,1240 . \quad \mathrm{MS} m / z: 156\left(\mathrm{M}^{+}, \mathrm{C}_{7} \mathrm{H}_{8} \mathrm{O}_{4}\right) .{ }^{1} \mathrm{H}-\mathrm{NMR}$ $\delta_{\mathrm{TMS}}^{\mathrm{CD}_{3} \mathrm{OD}}: 6.47(1 \mathrm{H}, \mathrm{m}), 4.71(1 \mathrm{H}, \mathrm{m}), 4.21(1 \mathrm{H}, \mathrm{ddd}, J=14.1,1.8,1.0 \mathrm{~Hz}), 4.13(1 \mathrm{H}$, ddd, $J=14.1,1.8,1.0 \mathrm{~Hz}), 3.78(1 \mathrm{H}$, ddd, $J=3.8,2.5,1.2 \mathrm{~Hz}), 3.39(1 \mathrm{H}, \mathrm{d}, J=3.8 \mathrm{~Hz})$. ${ }^{13} \mathrm{C}-\mathrm{NMR} \quad \delta_{\mathrm{TMS}}^{\mathrm{CD}_{3} \mathrm{OD}}: 195.2,142.1,135.7,65.9,59.5,55.3,54.4$.

The ${ }^{1} \mathrm{H}-\mathrm{NMR}$ spectrum and optical rotation of toxin II were completely identical with those of $(+)$-epoxydon ${ }^{1)}$.

\section{Necrotic effects of toxin I and II on leaves of sugarcane and other plants}

Within $24 \mathrm{hr}$ the leaves of susceptible and moderately resistant sugarcane cultivars treated with the solutions of toxin I and II developed brown lesions with a distinct red margin. The oval to spindle shaped lesions enlarged as the incubation continued, finally resulting in elongated-spindle-shaped lesions. These lesions were very similar to the naturally occurring symptoms caused by S. sacchari. Relationship between the 

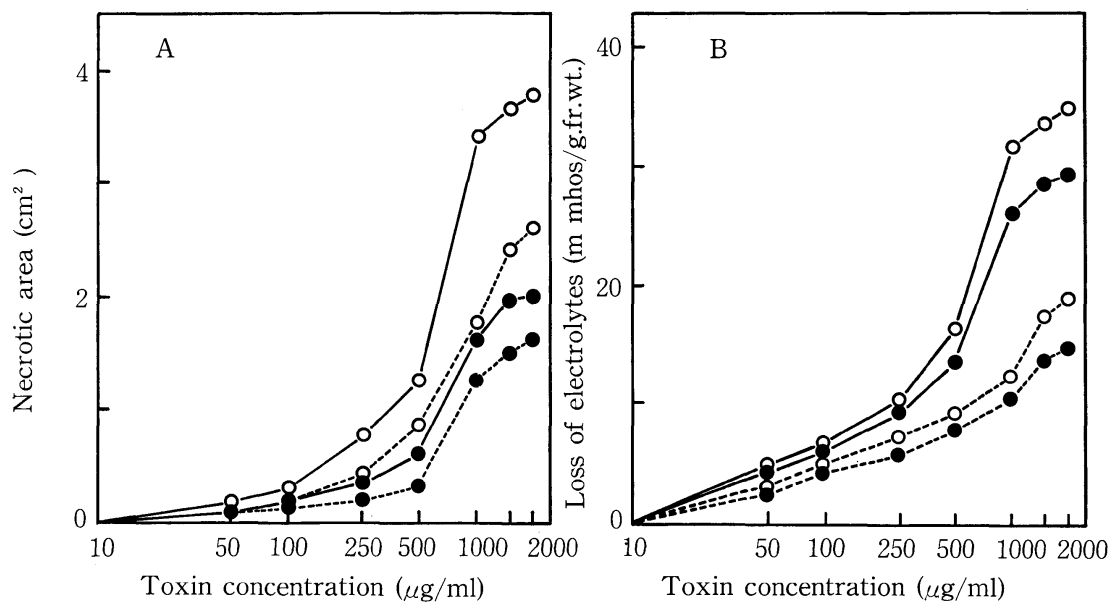

Fig. 1. Dose-dependent effects of toxins on necrotic leaf area formed (A) and electrolyte loss from sugarcane leaves (B). Leaf tissues of susceptible IRK67-1 (O) and moderately resistant $\mathrm{NCo} 376$ (O) sugarcane were treated with toxin I (…..) or II $(-)$ as described in the text. Necrosis was observed $72 \mathrm{hr}$ after toxin treatment, and electrolyte loss was determined $4 \mathrm{hr}$ after treatment and represented by subtracting value of untreated control from values of toxin-treated sample.

Table 2. Sensitivity of sugarcane leaves to Stagonospora sacchari toxins

\begin{tabular}{l|c|c|c}
\hline \hline \multirow{2}{*}{ Cultivar } & \multirow{2}{*}{ Disease reactiona } & \multicolumn{2}{|c}{ Dilution end point for leaf necrosis ${ }^{\mathrm{b})}$} \\
\cline { 3 - 4 } & & Toxin I & Toxin II \\
\hline Co 290 & S & $30 \mu \mathrm{g} / \mathrm{ml}$ & $25^{\mu \mathrm{g} / \mathrm{ml}}$ \\
CP 36-105 & S & 75 & 100 \\
IRK $67-1$ & S & 50 & 40 \\
NCo 310 & S & 50 & 50 \\
CP 43-32 & S & 100 & 100 \\
F 160 & M & 300 & 200 \\
NCo 376 & M & 100 & 100 \\
POJ 2878 & M & 200 & 200 \\
RK 65-37 & M & 200 & 250 \\
RK 82-1049 & M & 250 & 200 \\
\hline
\end{tabular}

a) $\mathrm{S}$ : susceptible and $\mathrm{M}$ : moderately resistant in field observations.

b) Necrosis was observed $24 \mathrm{hr}$ after toxin treatment.

toxin concentration and necrotic area showed a sigmoidal curve at the concentrations from 10 to $2,000 \mu \mathrm{g} / \mathrm{ml}$ of both toxin I and II (Fig. 1A). The threshold concentration induced leaf necrosis by toxin I was found to be $30 \mu \mathrm{g} / \mathrm{ml}$ for the cultivar IRK67-1, while by toxin II it was $25 \mu \mathrm{g} / \mathrm{ml}$. Necrotic area, however, was greater by toxin II than by toxin I. Necrotic reaction in the moderately resistant cv. NCo376 was smaller than in the susceptible cv. IRK67-1. Generally speaking, moderately resistant cultivars had somewhat higher threshold concentrations for leaf necrosis with both toxins (Table 2).

In addtion, both toxin I and II induced necrosis on leaves of many kinds of plants, not only monocotyledonous such as barley, maize, oats, paddy rice, sorghum and wheat 
but also dicotyledonous such as Japanese pear, tomato and rough lemon. Their threshold concentrations for both toxins ranged between 75 to $250 \mu \mathrm{g} / \mathrm{ml}$, except maize and sorghum whose concentrations were comparable to those of susceptible cultivars of sugarcane.

\section{Effects of toxin I and II on loss of electrolytes from leaf tissues}

Both toxin I and II caused a marked increase in electrolyte leakage from leaf tissues of susceptible and moderately resistant sugarcane cultivars within $1 \mathrm{hr}$ after treatment. The electrolyte loss increased with time. Their extent was greater in susceptible cv. than in moderately resistant cv. Analysis by atomic absorption spectrometry showed that potassium was the principal cation in the leaked electrolytes, and sodium, calcium and magnesium were no more than a tenth in amount, respectively. The relationships between toxin I and II concentrations and amounts of leaked electrolytes showed a sigmoidal curve, respectively, which was similar to that obtained in necrotic reaction on leaves (Fig. 1B).

\section{Relationships between susceptibility to leaf scorch and toxin sensitivity among sugarcane cultivars}

Ten cultivars of sugarcane usually known to be susceptible and moderately resistant in the field were re-investigated with their susceptibility to leaf scorch by spore inoculation of ten different isolates of $S$. sacchari, which were recently isolated from the

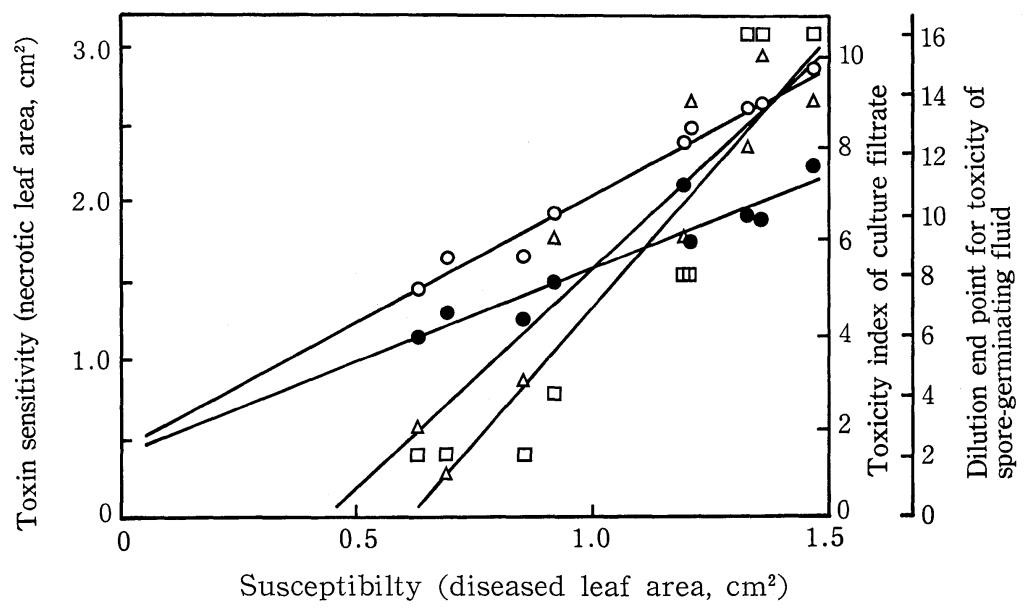

Fig. 2. Scatter diagram of sugarcane cultivars for susceptibility to leaf scorch versus toxin sensitivity. The susceptibility was determined according to diseased leaf area caused by spore inoculation. The toxin sensitivity was recorded with necrotic leaf area induced $72 \mathrm{hr}$ after the treatment of $1000 \mu \mathrm{g} / \mathrm{ml}$ solutions of toxin I (O) and II (O). Dilution end point for toxicity of spore-germinating fluid $(\square)$ on sugarcane cultivars was determined by leaf necrosis method using the concentrated fluid to a tenth in volume. Toxicity index of culture filtrate $(\triangle)$ on sugarcane cultivars was indicated by a cumulative numerical with a cultivar whose leaf necrosis occurred $72 \mathrm{hr}$ after the treatment by a dilution series $(10,50,100,250$ and 500 times) of culture filtrate was scored as follows: highly damaged, 3 ; moderately damaged, 2; slightly damaged, 1 and not damaged, 0 for each dilution. 
typical scorch lesions on susceptible leaves of sugarcane grown in Okinawa islands. All the ten isolates were found to have an ability to infect all the ten cultivars used within $48 \mathrm{hr}$ after inoculation. The necrotic area observed $72 \mathrm{hr}$ after inoculation was found to vary from 2.6 to less than $0.1 \mathrm{~cm}^{2}$ with the virulence of isolates as well as the susceptibility of cultivars. Among the cultivars examined, however, the disease severity based on their ranking could be grouped into three categories, viz., highly susceptible (Co290, NCo310 and IRK67-1), susceptible (CP43-32 and CP36-105) and moderately resistant (NCo376, RK65-37, POJ2878, F160 and RK82-1049), but no resistant cultivar was detected.

Sensitivities of the sugarcane cultivars to $1,000 \mu \mathrm{g} / \mathrm{ml}$ toxin I and II, germ-free culture filtrate and spore-germinating fluid of virulent isolate SSI-1 were scored by necrosis assay (Fig. 2). The regression of the leaf scorch susceptibility ( $x$ ) and the necrotic leaf area induced by toxin among the sugarcane cultivars tested (y) was significant $(\mathrm{p}=0.05)$ for both toxin $\mathrm{I}(\mathrm{r}=+0.950, \mathrm{y}=1.181 \mathrm{x}+0.391)$ and for toxin II $(\mathrm{r}=$ $+0.989, \mathrm{y}=1.614 \mathrm{x}+0.451)$, respectively. A comparison of the two regression lines indicated that the toxin II may be more active to induce necrosis than toxin I. Similar, but slightly less significant, correlations were found in the scores with the susceptibility versus the dilution end point of spore-germinating fluid for leaf necrosis and with the susceptibility versus the accumulated toxicity index for necrosis induced by culture filtrate.

\section{Release of toxins from germinating spores}

Pycnospores of the virulent isolate SSI-1 were collected from the mycelial mats laden with a plenty of pycnidia, and washed with distilled water 3 times by a mild centrifugation at $350 \times \mathrm{g}$ for $3 \mathrm{~min}$ to remove toxins produced by mycelia. The washed spore suspension $\left(5 \times 10^{5}\right.$ spores $\left./ \mathrm{ml}, 250 \mathrm{ml}\right)$ was spread on six layers of cheesecloth and

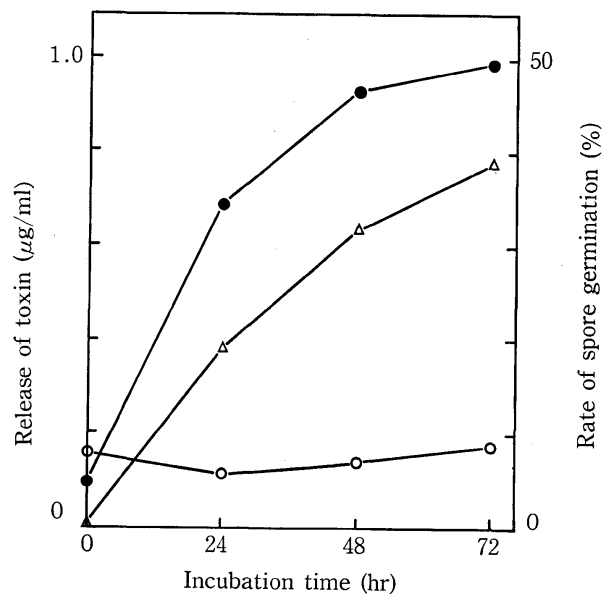

Fig. 3. Release of toxin I and II during spore germination. Spore germination rate $(\Delta)$ was observed microscopically. The spore-germinating fluid was extracted with ethyl acetate and the extract was applied to HPLC for determination of toxin I (O) and II (O). 
incubated at $20 \mathrm{C}$. Germination rate of spores and release of toxin I and II during spore germination into the germination fluid are shown in Fig. 3. The rate of spore germination was unusually slow: only $40 \%$ germination was attained in $72 \mathrm{hr}$ incubation; germ tubes grew long and developed into mycelium in $96 \mathrm{hr}$ although it is not shown in this Figure. In spite of repeated washing both toxins were released from ungerminated spores as indicated with the levels at $0 \mathrm{hr}$ incubation $(0.11 \mu \mathrm{g} / \mathrm{ml}$ for toxin I and $0.163 \mu \mathrm{g} / \mathrm{ml}$ for toxin II). Release of toxin I significantly increased as germination proceeded (about $1 \mu \mathrm{g} / \mathrm{ml}$ in $72 \mathrm{hr}$ ) while that of toxin II did not change significantly.

\section{Discussion}

The present study showed that Stagonospora sacchari produces great amounts of at least two phytotoxins in spore-germinating fluids as well as in cultures. Both toxin I and II caused necrotic lesions similar to those of the scorch symptoms on sugarcane leaves in the field. Toxin II seemed to be a little more potent, because it could induce larger lesions than toxin I did, regardless of the fact that they shared almost same dilution end point for toxicity. An intensive spectral analysis for chemical structure indicated that toxin I is identical with 6 -methylsalicylic acid (6-MSA) ${ }^{15}$ ) and toxin II $(+)$-epoxydon ${ }^{1)}$.

From the histological investigations on the leaf infection by $S$. sacchari, $\mathrm{Wu}^{20)}$ suggested that the hyphal penetration to guard cells and mesophyll cells may be expedited by a chemical substance secreted by the pathogen. At present there is no direct evidence, but both toxin I and/or II may be a possible candidate for such predisposing factor because the germinating pycnospores and the growing mycelia could produce a plenty of the toxins. Moreover, toxin I and II caused a rapid and dose-dependent increase in electrolyte loss, mainly potassium, from leaf tissues, suggesting the occurrence of membrane dysfunction in the cells. As indicated in host-specific toxins from Alternaria $^{9}$, the modulated or impaired membrane function might relate to a key event to induce the accessibility in the cells to invading fungi.

The toxins from Stagonospora seemed to be non-specific in the activity against plants. Both toxin I and II have rather broad spectra of plants for toxin sensitivity: necrosis was induced on leaves of sensitive plants including susceptible host at the concentrations higher than $25 \mu \mathrm{g} / \mathrm{ml}$ and on leaves of less-sensitive plants at a concentration of $250 \mu \mathrm{g} / \mathrm{ml}$. Maize and sorghum were found to be as sensitive as susceptible sugarcane. Lo et al. ${ }^{12)}$ described that isolates of Stagonospora from Japanese plume grasses, Miscanthus sinensis and $M$. japonicus can infect sugarcane leaves and vice versa, S. sacchari can infect leaves of these two grasses in addition to sorghum, proposing the identity of both pathogens. Yamauchi ${ }^{22}$ also reported that $S$. sacchari is pathogenic to needlegrass, Imperata cylindrica, napier grass, Pennisetum purpureum and Japanese plume grasses, and the importance of diseased leaves of them as a possible over-winter source of the inoculum in the field. From the view point of infection chain, host range of $S$. sacchari should be re-investigated.

More surprisingly, among sugarcane cultivars tested, a highly positive correlation 
was observable between the toxin sensitivity determined by necrotic area on leaves and the disease susceptibility determined by spore inoculation on leaves. Their orders in sensitivity appeared to match with the order in leaf scorch susceptibility scored in the field condition. For screening sugarcane resistant against leaf scorch, artificial inoculation in greenhouses has so far been recommended ${ }^{21)}$. However, the toxins with selectivity may be applicable to select sugarcane seedlings resistance to leaf scorch with accuracy and valuable savings in time as well as labor, as reported with eye spot disease of sugarcane ${ }^{2}$.

6-MSA is well known as a characteristic intermediate metabolite on the biosynthetic pathway for tetraketides widespread in fungal world ${ }^{18)}$. As a phytotoxin, however, it was isolated from Penicillium decumbens ${ }^{3)}$, P. urticae ${ }^{3,17)}$ and Phyllosticta sp. (perfect stage: Leptotrochia trifolii) ${ }^{16)}$ causing Kuro-hagare disease on red and white clovers. Meanwhile, (+)-epoxydon, an advanced metabolite of 6-MSA, was also isolated as a phytotoxin from Ascochyta chrysanthemi (Mycosphaella ligulicola) ${ }^{1)}$ causing chrysanthemum ray blight, Phoma chrysanthemi ${ }^{1)}$, Phoma sp. ${ }^{4)}$, and Phyllosticta sp. ${ }^{16)}$. In the taxonomical view point it is very interesting that, except for mutant Penicillium ${ }^{17}$, these 6 -MSA and epoxydon-producing fungi all belong to the Sphaeropsidales in Deutromycetes; the abundant production of $6-\mathrm{MSA}$ and the related metabolites might have a physiological significance in pycnidium-forming fungi such as a role of self-inhibitor for spore germination.

One of the authors (P. V.) whishes to express his sincere thanks to the Matsumae International Foundation (Tokyo) for financial support.

\section{Literature cited}

1. Assante, G., Camarda, L., Merlini, L. and Nashini, G. (1981). Phytochemistry $20: 1955-1957$.

2. Byther, R. S. and Steiner, G. W. (1972). Phytopathology $62: 466-470$.

3. Beresteskii, O. A., Elisashvili, T. A. and Borokov, A. V. (1987). S-kh. Biol. 13: 868-871.

4. Closse, A., Mauli, R. and Sigg, H. P. (1966). Helv. Chim. Acta 49 : 204-213.

5. Hokama, K. (1983). Bull. Okinawa Agr. Expt. Stn. $8: 1-4$.

6. Hokama, K. (1984). Proc. Assoc. P1. Prot. Kyushu $30: 38-40$.

7. Hokama, K. (1985). Ibid. $31: 32-34$.

8. Kumaraswamy, S. (1981). Ind. Sugar Crops Jour. $8: 24-25$.

9. Kohmoto, K., Otani, H. and Nishimura, S. (1987). In Molecular Determinants of Plant Diseases (Nishimura, S. et al. eds.). Japan Sci. Soc. Press, Tokyo/Springer-Verlag, Berlin. pp. 127-143.

10. Lo, T. T. (1961). In Sugar Cane Diseases of the World, vol. 1 (Martin, J. P. et al. eds.). Elsevior, New York. pp. 209-218.

11. Lo, T. T. and Ling, K. C. (1950). Sugar Cane Res. $4: 323-335$.

12. Lo, T. C., Chu, H. T. and Chiu, J. C. (1953). Rep. Taiwan Sugar Expt. Statn. $10: 105-116$.

13. Matsumoto, T. (1955). Ibid. $13: 81-113$.

14. Otani, H., Morikawa, M., Nishimura, S. and Kohmoto, K. (1977). Ann. Phytopath. Soc. Japan $43: 562-568$.

15. Sakamura, S., Chida, T., Ito, J. and Sakai, R. (1971). Agr. Biol. Chem. $35: 1810-1811$.

16. Sakamura, S., Niki, H., Obata, Y., Sakai, R. and Matsumoto, T. (1969). Ibid. 33:698-703.

17. Sekiguchi, J. and Gaucher, G. M. (1979). Can. J. Microbiol. $25: 881-887$.

18. Turner, W. B. and Aldridge, D. C. (1983). Fungal Metabolites II. P. 631. Academic Press, London and New York.

19. Venkatasubbaiah, P., Kohmoto, K., Otani, H., Hamasaki, T. and Hokama, K. (1986). Ann. Phytopath. Soc. Japan $52: 529$ (Abstr. in Japanese). 
20. Wu, J.-H. (1955). Rep. Taiwan Sugar Expt. Statn. $13: 105-108$.

21. Wang, Z. N. and Lee, C. S. (1980). Rep. Taiwan Sugar Res. Inst. $88: 55-62$.

22. Yamauchi, S. (1970). Okinawa Agr. $9: 589-592$.

\section{和 文 摘 要}

P. VenKATASUBBAIAH ・ 甲元啓介・尾谷 浩・濱崎 敞・中島廣光・外間数男 :サトゥキビ葉烵病菌の生 成する毒素

サトウキビ葉焼病菌 Stagonospora sacchari は, 柄胞子発芽や菌系伸長時に, 2 種類の壊死斑形成毒素 I お よびIIを生成・分泌した。それぞれの UV, IR, MS, NMR スペクトルなどの解析によって, 毒素 I は 6-メ チルサルチル酸, 毒素IIは（十）-エポキシドンと同定された。感受性サトウキビ葉における壊死斑形成最少濃 度は前者で $30 \mu \mathrm{g} / \mathrm{ml}$, 後者で $25 \mu \mathrm{g} / \mathrm{ml}$ であった。中度抵抗性品種ではいずれす約 $250 \mu \mathrm{g} / \mathrm{ml}$ であった。両 毒素は葉組織からの電解質の異常漏出を誘導し, その主なカチオンは $\mathrm{K}^{+}$であった。供試サトウキビ品種の胞 子接種による本病䍜病性の程度と毒素感受性との間には高い正の相関が認められた。 